\author{
Н.Г. Горовенко ${ }^{1,3}$, З.І. Россоха ${ }^{1,2}$, С.П. Кир'яченко ${ }^{1,2}$, Л.П. Шейко ${ }^{1,3}$, Л.І. Брішевац ${ }^{1,3}$ \\ 'ДУ «Інститут генетичної та регенеративної медицини НАМн України», Київ \\ ${ }^{2} Д 3$ «Референс-центр з молекулярної діагностики Міністерства охорони здоров'я України», Київ \\ ${ }^{3}$ Національна медична академія післядипломної освіти імені П.Л. Шупика, Київ
}

\title{
Особливості міжгенної та ген-факторної взаємодії у чоловіків із подружніх пар з безпліддям та репродуктивними втратами
}

Проаналізовано міжгенну та ген-факторну взаємодію поліморфних варіантів генів гемостазу (ITGA2a (C807T), ITGB3b (T1565C), FGB (C148T, G-455A), PAl-1 (-675 5G/4G), FII (G20210A), FV (G1691A)), фолатного обміну (MTHFR (C677T, A1298C), MTRR (A66G), MTR1 (A2756G), RFC1 (G80A)) та гена рецептора фолікулостимулюючого гормону (FSHr) (Ala307Thr, Ser680Asn) у 206 чоловіків із подружніх пар з безпліддям невстановленого генезу та ранніми репродуктивними втратами. Проведено порівняння отриманих результатів із застосуванням методів одно- та багатофакторного аналізу. Доведено наявність асоціації генів ITGB3b, ITGA2a, RFC1, FSHr та їх комбінацій із ризиком розвитку безпліддя учоловіків. Значущими булип'ять прогностичнихмоделей ризику: міжгенної взаємодії(PAI-1+ITGB3b + ITGA2a, MTHFR+ MTR1 + RFC1) та ген-факторної взаємодії(ITGB3b + протромбіновий час, MTHFR + MTR1 + RFC1 + тютюнопаління, FSHr + MTRR + обтяжена спадковість). Виявлені залежності свідчать про різноманітність індивідуальних патогенетичних механізмів розвитку безпліддя у чоловіків, що потребує застосування персоналізованого лікування.

Ключові слова: генетичний поліморфізм, репродуктивні розлади, чоловіки.

\section{Вступ}

Безпліддя у подружніх парах в останні десятиліття сягає 10$15 \%$, при цьому чоловічий фактор реєструють майже у половині випадків (Massart A. et al., 2012; Abarikwu S.O., 2013; Kliesch S. 2014; Agarwal A. et al., 2015; Jungwirth A. et al., 2015). Незважаючи на високу частоту виявлення ролі чоловічого фактора в безплідних подружніх парах, залишаються невідомими провідні генетичні порушення, що спричиняють зниження репродуктивної функції у чоловіків. До останнього часу серед тестів, які використовували для визначення генетичних факторів чоловічого безпліддя (ЧБ) у клінічній практиці, основними були дослідження, спрямовані на виявлення наявності мікроделецій Ү-хромосоми та/чи хромосомних аномалій, мутацій у гені муковісцидозу та андрогенового рецептора (Wosnitzer M.S., 2014). В окремих роботах показано наявність асоціації однонуклеотидного поліморфізму одного чи декількох генів із ЧБ та висловлено думку про його полігенну основу (Zorrilla M., Yatsenko A.N., 2013). Проте результати, отримані одними дослідниками, не завжди відтворювалися іншими при аналізі різних популяційних вибірок, і саме ця неоднозначність уповільнила використання даних подібних досліджень у клінічній практиці. В експериментальних роботах із залученням тваринних моделей із нокаутованими генами підтверджено полігенну основу порушень сперматогенезу та встановлено, що у механізми розвитку безпліддя залучено не менше ніж 388 генів (Massart A. et al., 2012). Процес сперматогенезу та дозрівання сперми контролюється взаємодією понад тисячі генів, але проведені повногеномні дослідження не визначили генів, асоційованих із безпліддям невстановленого генезу, тому що лише у невеликій кількості випадків виявлено одні й ті самі генетичні аномалії (Taneja S.S., 2014). У цих роботах відсутній поглиблений аналіз міжгенних та ген-факторних взаємодій з урахуванням різноспрямованих потенційних патогенетичних ланок при репродуктивних розладах, що зумовило мету виконання цієї роботи.

Мета - проведення у чоловіків із подружніх пар із безпліддям невстановленого генезу та ранніми репродуктивними втратами аналізу міжгенної та ген-факторної взаємодії поліморфних варіантів генів гемостазу (тромбоцитарного рецептора до колагену (ITGA2a) (C807T), тромбоцитарного рецептора фібриногену (ITGB3b) (T1565C), фібриногену (FGB) (C148T, G-455A), антагоніста тканинного активатора плазміногена 1-го типу (PAl-1) (-675 5G/4G), протромбіну (FII) (G20210A), фактора V (FV) (G1691A)), фолатного обміну (метилентетрагідрофолатредукта- зи (MTHFR) (С677Т, А1298C), метіонінсинтази-редуктази (MTRR) (A66G), метіонінсинтази (MTR1) (A2756G), транспортера фолатів (RFC1) (G80A)) та гена рецептора фолікулостимулюючого гормонy (FSHr) (Ala307Thr, Ser680Asn).

\section{Об'єкт і методи дослідження}

До дослідження залучено 206 чоловіків: 69 - із подружніх пар із безпліддям невстановленого генезу впродовж 5 років (1-ша група) та 137 - із подружніх пар із ранніми репродуктивними втратами в анамнезі (2-га група). Подружні пари направлено на медико-генетичне консультування для аналізу ймовірних та виявлення провідних генетичних чинників у розвитку безпліддя.

Критерії виключення з дослідження: аномалії каріотипу, ожиріння, соматична й онкологічна патологія, гострі та хронічні інфекційні захворювання у подружній парі, азооспермія та наявність делецій Ү-хромосоми у чоловіків.

Усі пацієнти надали результати проведених до звернення на медико-генетичне консультування клініко-лабораторних та інструментальних досліджень і заповнили опитувальний лист, у який вносилися дані про спосіб життя, професійні шкідливості та шкідливі звички. Усі пацієнти надали інформовану згоду на участь у дослідженні. На проведення дослідження отримано дозвіл етичного комітету Державної установи «Інститут генетичної та регенеративної медицини НАМН України».

Молекулярно-генетичне дослідження поліморфних варіантів генів системи згортання крові (FII - G20210A (rs1799963), FV G1691A Leiden (rs6025), FGB - C148T (rs1800787) та G-455A (rs1800790), ITGB3b - T1565C (rs5918), ITGA2a - C807T (rs1126643), PAl-1 - -675 5G/4G (rs1799889)), фолатного обміну (MTHFR - C677T (rs1801133), A1298C (rs1801131), MTR1 A2756G (rs1805087), MTRR - A66G (rs1801394), RFC1 - G80A (rs1051266)), гена FSHr (Ala307Thr (rs6165), Ser680Asn (rs6166)) проводили методами алельспецифічної полімеразної ланцюгової реакції (ПЛР) або ПЛР з подальшим аналізом поліморфізму довжини рестрикційних фрагментів.

Статистичний аналіз результатів проводили з використанням програмного пакета «MS Excel» та програми «SPSS 17.0». Достовірність відмінностей визначали із застосуванням критерію $\chi^{2}$ з поправкою Йєтса при рівні значущості $p<0,05$ (після корекції отриманих результатів з урахуванням множинних порівнянь). Асоціацію поліморфних варіантів генів та їх комбінацій з ризиком розвитку ЧБ досліджували за допомогою розрахунку відношення 
шансів (ВШ) з 95\% довірчим інтервалом (ДІ). Головні незалежні, а також спільні ефекти всіх проаналізованих генів, визначали з використанням статистичної програми мультифакторної просторової редукції (MDR) та пермутаційного тесту (MDR.pt).

\section{Результати та їх обговорення}

У пацієнтів обохгруп проаналізовано та порівняно результати 32 клініко-лабораторних показників, включаючи показники фолатного обміну і гемостазу, та особливості способу життя з опитувального листа у поєднанні з генетичним поліморфізмом (сімнадцятьма поліморфними варіантами) досліджених генів. За дослідженими клініко-лабораторними показниками достовірних відмінностей, окрім показників фолатного обміну, не виявлено. Відповідно до критеріїв європейських консенсусів та настанов (Stanger O. et al., 2003; Devalia V. et al., 2014; Wilcken B., 2017) riпергомоцистеїнемію (ГГЦ), яку реєструють при рівні гомоцистеїну >12 мкмоль/л, виявлено у пацієнтів обохгруп. Середній рівень гомоцистеїну у пацієнтів 2-ї групи був значуще вищий порівняно з пацієнтами 1-ї групи ( $<<0,05)$, відповідно значуще різнилися показники рівня вітаміну $\mathrm{B}_{12}(p<0,05)$. ГГЦ виявлено у $34,78 \%$ пацієнтів 1-ї та 37,96\% - 2-ї групи. Пацієнти обох груп мали обтяжений (випадками кардіоваскулярних та онкологічних захворювань і репродуктивних розладів) родовід (табл. 1).

Таблиця 1. Базова клініко-лабораторна характеристика пацієнтів

\begin{tabular}{|c|c|c|}
\hline \multirow{2}{*}{ Клініко-лабораторні показники } & \multicolumn{2}{|c|}{ Група } \\
\hline & 1-ша & 2-га \\
\hline \multicolumn{3}{|c|}{ Антропометричні } \\
\hline Вік, років & $35,23 \pm 0,62$ & $34,52 \pm 0,51$ \\
\hline Зріст, см & $177,4 \pm 1,73$ & $174,49 \pm 2,06$ \\
\hline Маса тіла, кг & $81,9 \pm 3,71$ & $79,45 \pm 1,49$ \\
\hline \multicolumn{3}{|c|}{ Порушення сперматогенезу, \% } \\
\hline Олігоспермія & 43,48 & 38,69 \\
\hline Астенозооспермія & 14,49 & 21,17 \\
\hline Нормозооспермія & 13,14 & 13,14 \\
\hline \multicolumn{3}{|c|}{ Середній рівень концентрації в плазмі крові $(\mathrm{M} \pm \mathrm{m})$} \\
\hline Гомоцистеїн, мкмоль/л & $12,01 \pm 0,92$ & $18,16 \pm 1,80$ \\
\hline Фолієва кислота, нг/мл & $11,18 \pm 1,25$ & $8,56 \pm 0,68$ \\
\hline Вітамін $\mathrm{B}_{1,}, \mathrm{пг} /$ мл & $500,71 \pm 51,10$ & $316,55 \pm 28,61$ \\
\hline \multicolumn{3}{|c|}{ Показники коагулограми } \\
\hline Протромбіновий індекс, \% & $93,40 \pm 4,23$ & $97,01 \pm 6,29$ \\
\hline Протромбіновий час, с & $12,05 \pm 0,34$ & $11,5 \pm 0,24$ \\
\hline $\begin{array}{l}\text { Активований частковий тромбопластино- } \\
\text { вий час, с }\end{array}$ & $31,06 \pm 1,83$ & $28,44 \pm 0,65$ \\
\hline Тромбіновий час, с & $18,84 \pm 0,52$ & $18,23 \pm 0,45$ \\
\hline Фібриноген, г/л & $2,59 \pm 0,14$ & $2,54 \pm 0,11$ \\
\hline \multicolumn{3}{|c|}{ Фактори ризику, \% } \\
\hline Тютюнопаління & 17,39 & 24,09 \\
\hline \multicolumn{3}{|c|}{ Обтяжена спадковість, \% } \\
\hline Онкологічні захворювання & 7,25 & 12,41 \\
\hline Кардіоваскулярні захворювання & 27,54 & 28,47 \\
\hline Репродуктивні розлади & 4,35 & 9,48 \\
\hline Інше & 8,70 & 14,60 \\
\hline
\end{tabular}

у 14,49\% пацієнтів 1-ї групи достовірно частіше виявляли генотип 1565 CC за геном ITGB3b порівняно з 1,46\% пацієнтів 2-ї групи ( $\chi^{2}=11,9, p=0,001 ;$ ВШ 11,44; 95\% ДІ 2,43-53,8). У 1-й групі також спостерігали підвищення частоти генотипу 807 ТТ за геном ITGA2a $-27,54 \%$ порівняно з $10,21 \%$ у 2 -й групі $\left(x^{2}=8,98, p=0,003\right.$; ВШ 3,$34 ; 95 \%$ ДІ 1,55-7,17). В осіб із генотипом $807 \mathrm{CC}$ за геном ITGA2а виявлено зниження ризику безпліддя $\left(\chi^{2}=4,41, p=0,036\right.$; ВШ 0,49; 95\% ДІ 0,27-0,92). Отже, гени ITGB3b та ITGA2а асоційовані з розвитком ЧБ.

При аналізі впливу генів системи гемостазу на розвиток ЧБ з використанням методу MDR отримано 7 моделей міжгенної взаємодії. Значущими були 3-, 4- та 5-локусна моделі (табл. 2).

Таблиця 2. Прогностичні моделі міжгенних взаємодій у розвитку ЧБ

\begin{tabular}{|c|c|c|c|}
\hline $\begin{array}{c}\text { Кіль- } \\
\text { кість } \\
\text { локусів }\end{array}$ & Ген/комбінації генів у моделі & $\begin{array}{c}\text { Точність } \\
\text { моделі, } \\
\%\end{array}$ & $\begin{array}{c}\text { Відтворю- } \\
\text { ваність } \\
\text { моделі }\end{array}$ \\
\hline 1 & ITGA2a C807T & 51,34 & $9 / 10$ \\
\hline 2 & FGB C148T/ITGA2a & 56,04 & $5 / 10$ \\
\hline $3^{* *}$ & PAI-1, ITGB3b, ITGA2a & 65,86 & $10 / 10$ \\
\hline $4^{*}$ & FGB C148T/PAI-1, ITGB3b, ITGA2a & 64,77 & $10 / 10$ \\
\hline $5^{*}$ & FGB_C148T/PAl-1, ITGB3b, FV, ITGA2a & 62,58 & $8 / 10$ \\
\hline 6 & FGB C148T/PAl-1, ITGB3b, FII, FV, ITGA2a & 60,02 & $8 / 10$ \\
\hline 7 & FGB C148T/-455GA/PAI-1, ITGB3b, FIl, FV, ITGA2a & 60,02 & $10 / 10$ \\
\hline
\end{tabular}

Достовірність моделі за пермутаційним тестом: ${ }^{\star} p<0,05,{ }^{* *} p<0,01$.
Прогностична цінність була найкращою у 3-локусній моделі: (PAl-1, ITGB3b, ITGA2a), тому дослідники вважали за необхідне проаналізувати виявлений взаємозв'язок. Для генів, що становили основу значущих прогностичних моделей, підраховано зв'язок з іншими генами гемостазу у розвитку безпліддя, а також проаналізовано поєднаний вплив комбінацій генотипів (табл. 3).

Таблиця 3. Значущі комбінації генотипів за поліморфними варіантами генів ITGB3b, ITGA2a, FGB, PAI-1, FV, асоційовані з ризиком ЧБ

\begin{tabular}{|c|c|c|c|c|c|c|}
\hline \multirow{2}{*}{ Генотип } & \multicolumn{2}{|c|}{ Група, n/\% } & \multirow{2}{*}{$x^{2}$} & \multirow{2}{*}{ ВШ } & \multirow{2}{*}{ 95\% ДІ } & \multirow[b]{2}{*}{ p } \\
\hline & 1-ша & 2-га & & & & \\
\hline \multicolumn{7}{|c|}{ ITGB3b_T1565C/ITGA2a_C807T } \\
\hline 1565CC/807TT & $7 / 10,14$ & $0 / 0,00$ & 11,5 & - & - & 0,001 \\
\hline \multicolumn{7}{|c|}{ ITGB3b_T1565C/FGB_C148T } \\
\hline $1565 \mathrm{CC} / 148 \mathrm{CC}$ & $5 / 7,25$ & $2 / 1,46$ & 4,68 & 5,27 & $1,00-27,92$ & 0,031 \\
\hline $1565 \mathrm{CC} / 148 \mathrm{CT}$ & $5 / 7,25$ & $0 / 0,00$ & 7,34 & - & - & 0,007 \\
\hline $1565 \pi / 148 \pi T$ & $4 / 5,80$ & $0 / 0,00$ & 5,34 & - & - & 0,021 \\
\hline \multicolumn{7}{|c|}{ ITGB3b_T1565C/FGB_G-455A } \\
\hline $1565 \mathrm{CC} /-455 \mathrm{GG}$ & $6 / 8,69$ & $2 / 1,46$ & 4,64 & 6,43 & $1,26-32,8$ & 0,031 \\
\hline $1565 \mathrm{CC} /-455 \mathrm{GA}$ & $4 / 5,80$ & $0 / 0,00$ & 5,34 & - & - & 0,021 \\
\hline \multicolumn{7}{|c|}{ ITGA2a_C807T/FGB_C148T } \\
\hline $807 \mathrm{CT} / 148 \mathrm{CC}$ & $11 / 15,94$ & $40 / 29,20$ & 4,33 & 0,46 & $0,22-0,97$ & 0,038 \\
\hline $807 T \mathrm{~T} / 148 \mathrm{CC}$ & $14 / 20,29$ & $11 / 8,03$ & 5,37 & 2,92 & $1,25-6,83$ & 0,020 \\
\hline \multicolumn{7}{|c|}{ ITGA2a_C807T/FGB_G-455A } \\
\hline $807 \mathrm{CC} /-455 \mathrm{GA}$ & $6 / 8,69$ & $31 / 22,63$ & 5,14 & 0,33 & $0,13-0,82$ & 0,023 \\
\hline 807CT/-455GG & $11 / 15,94$ & $40 / 29,19$ & 3,98 & 0,46 & $0,22-0,97$ & 0,047 \\
\hline $807 T T /-455 G G$ & $15 / 21,73$ & $11 / 8,03$ & 6,63 & 3,18 & $1,37-7,38$ & 0,010 \\
\hline \multicolumn{7}{|c|}{ FGB_C148T/FGB_G-455A } \\
\hline $148 \mathrm{TT} / 455 \mathrm{AA}$ & $5 / 7,25$ & $2 / 1,46$ & $4, \overline{68}$ & 5,27 & $1,00-27,92$ & 0,031 \\
\hline \multicolumn{7}{|c|}{ PAl-1_-675 5G/4G/FV_G1691A } \\
\hline 4G4G/1691GA & $4 / 5,80$ & $0 / 0,00$ & 5,34 & - & - & 0,021 \\
\hline
\end{tabular}

Як видно (див. табл. 3), у пацієнтів з генотипом 1565CC за геном ITGB3b у поєднанні з генотипами 148CC, 148CT та -455GG, -455GA за геном FGB - підвищений ризик безпліддя. У пацієнтів 2-ї групи взагалі не виявлено комбінацій генотипу 1565CС з гетерозиготними варіантами гена FGB. У жодного пацієнта обох груп не виявлено комбінацій генотипів 1565CC/148TT, 1565CC/-455AА за генами ITGB3b та FGB.

Виявлено підвищенучастотукомбінаціїгенотипів 1565TT/148TТ за генами ITGB3b та FGB у пацієнтів 1-ї групи порівняно з 2-ю (причому у 2-й групі таких пацієнтів не виявлено) та генотипів 148TT/-455AA за геном FGB. Частота комбінації генотипів 1565CC/807TT за генами ITGB3b та ITGA2а також була підвищена у пацієнтів 1-ї групи, а у 2-й таких пацієнтів не виявлено.

Комбінації генотипів 807CT/-455GG, 807CT/148CC, 807CC/455GA, 807CC/148CT за генами ITGA2а та FGB були значуще підвищеними у 2-й групі, тобто знижували ризик безпліддя. У пацієнтів 1-ї групи була достовірно підвищена частота комбінації генотипів 4G4G/1691GA за генами PAl-1 та FV. Отже, комбінації за генами, асоційованими з порушеннями гемостазу, мають важливе значення для розвитку ЧБ.

При аналізі впливу комбінації факторів (ген-факторнихвзаємодій) з урахуванням генів системи гемостазу на зростання ризику безпліддя виявили значущий вплив у прогностичній моделі: протромбіновий час та варіант гена ITGB3b (константа -4,995): 1565 TC (коефіцієнт регресії 0,352; стандартна похибка 0,143; p=0,013; ВШ 1,42) та 1565CC (коефіцієнт регресії 0,288; стандартна похибка 0,130; $p=0,026$; ВШ 1,33).

Протромбіновий час - інтегративний показник, який характеризує зовнішній шлях згортання крові; при його зниженні підвищується ризик тромботичних подій. Найважливіша особливість фізіологічних процесів при активації тромбоцитів - модифікація комплексу мембранних глікопротеїдів Ilb-IIla. У результаті конформаційних змін комплекс набуває здатності до зв'язування фібриногену. Внаслідок відбувається агрегація, яка закінчується формуванням в ділянці пошкодження судинної стінки тромбоцитарного тромбу. Рецептор GPIIb/IIla є основним тромбоцитарним рецептором, молекулярні дефекти якого можуть призводити до гіперагрегації тромбоцитів. Комплекс складається із двох субодиниць Ilb i llla, які кодуються генами, розміщеними близько один до одного на 17-й хромосомі. ITGB3 (GPIIla) кодує білковий компонент тромбоцитарного рецептора фібриногену. Цей рецептор забезпечує взаємодію тромбоцитів із фібриногеном, в результаті чого відбувається агрегація тромбоцитів і утворення тромбу. Точкова мутація C1565T у другому екзоні гена ITGB3b призводить до заміни лейцину (Leu) на пролін (Pro) в 33-му положенні білка 
GPIIla (rs5918). Тромбоцити, що несуть /TGB3-Pro33, мають нижчий поріг активації (більш схильні до агрегації), і при варіанті 1565C ризик тромботичних подій підвищений (Kucharska-Newton A.M et al., 2011; Зотова Т.Ю., Мяндина Г.И., 2013). Тому, ймовірно, наявність варіантів гена /TGBЗЬ у комбінації зі зниженим протромбіновим часом супроводжується згущенням крові в мікроциркуляторному руслі та погіршенням адгезивних властивостей клітин.

Різні порушення фолатного обміну і транспорту фолатів, внаслідок чого виникають як ГГЦ, так і гіпофолатемія чи гіперфолатемія, раніше досліджені нами як чинники розвитку тромбофілічних розладів, жіночого безпліддя та несприятливого перебігу антенатального періоду і погіршеного здоров'я нащадків (Горовенко Н.Г. и соавт., 2011; Rossokha Z., Gorovenko N., 2017).

У напрямку дослідження чоловічого здоров'я подібних робіт було обмаль (Жилкова Е.С., 2017), хоча в експериментальних роботах на тваринах неодноразово доведена важливість фолатного обміну для репродуктивної функції (Hong H.H. et al., 2017).

При проведенні порівняльного аналізу одержаних нами результатів молекулярно-генетичних досліджень встановлено, що у чоловіків 1-ї групи достовірно частіше виявляли генотип 80АА за геном RFC1 ( $\mathrm{X}^{2}=3,94, \mathrm{p}=0,048 ; \mathrm{BШ} \mathrm{1,90;95 \%} \mathrm{ДІ} \mathrm{1,00-3,61).}$ За результатами проведених порівнянь комбінацій генотипів у групах виявлено асоціацію поєднання генотипу 80АА за геном $R F C 1$ з гомозиготними варіантами 2756АA за геном $M T R 1\left(\chi^{2}=3,96\right.$, $\mathrm{p}=0,047 ;$ ВШ 2,24; 95\% ДІ 1,00-5,01), 677CC за геном MTHFR $\left(\chi^{2}=4,45, p=0,035\right.$; ВШ 3,06; $95 \%$ ДІ 1,17-8,00) та розвитком безпліддя.

Поліморфізм G80A гена RFC1 є одним із варіантів генів транспортерів фолатів, що модифікують вплив відомих та досліджених варіантів генів MTHFR, MTR1 (Bueno O. et al., 2016), у тому числі різноспрямовано, що підтверджено й нашими результатами. Встановлено, що поєднання генотипу 80AA за геном RFC1 із функціональними генотипами за генами MTHFR, MTR1 підвищувало ризик безпліддя.

Функціональна роль RFC1 полягає у зв'язуванні та поглинанні фолату, регуляції його внутрішньоклітинного транспорту, цей процес залежить від рівня фолієвої кислоти у сироватці крові та наявного чи відсутнього додаткового споживання фолієвої кислоти. Із експериментальних робіт та окремих досліджень відомо, що в осіб з наявним алелем 80A за геном RFC1 погіршений внутрішньоклітинний транспорт фолатів (Gelineau-van Waes J. et al., 2008; Pietrzik K. et al., 2010; Visentin M. et al., 2014), який, ймовірно, більш важливий для репродуктивної функції, аніж метаболічні перетворення фолієвої кислоти за участю MTHFR та MTR1.

При порівнянні груп встановлено значущу 5-локусну прогностичну модель ризику, предиктивна цінність якої була 59,26\% (рисунок).

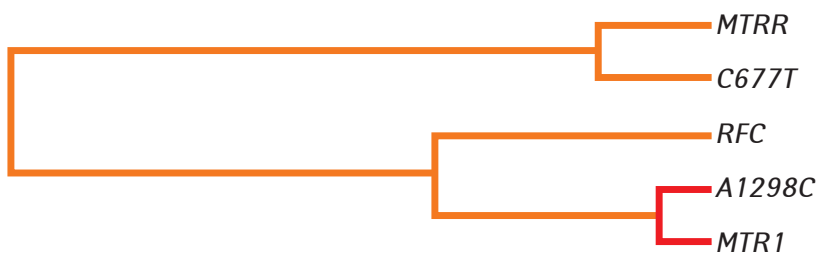

Рисунок. Дендрограма міжгенної взаємодії MTHFR, MTRR, MTR1, RFC1 у розвитку ЧБ

Поєднання нефункціональних генотипів за генами фолатного обміну частіше виявляли у пацієнтів 1-ї групи. У 4,35\% пацієнтів 1-ї групи виявлено комбінацію генотипів 2756GG/1298CС за генами MTR1, MTHFR, в той час як у пацієнтів 2-ї групи такого поєднання генотипів взагалі не виявлено $\left(\chi^{2}=6,05 ; p=0,014\right)$. Комбінація генотипів 2756AA/677CC за генами MTR1 та MTHFR була знижена у пацієнтів 1-ї групи порівняно з 2-ю $\left(X^{2}=4,04, p=0,045\right.$; ВШ 0,49; 95\% ДІ 0,24-0,99).

Виражений модифікуючий вплив на ризик безпліддя (табл. 4) виявлено для генотипу 80AА за геном RFC1 у поєднаннях із генотипом 807TT за геном ITGA2а та генотипом 1565CC за геном ITGB3b (у 2-й групі взагалі не було пацієнтів із такою комбінацією генотипів). Також достовірно частіше у 1 -й групі виявлена комбінація генотипів 80AA/148CC за генами FGB та RFC1.
Таблиця 4. Значущі комбінації генотипів за генами RFC1, ITGA2a, ITGB3b, FGB, MTRR, MTR1, FSHR, асоційовані з ризиком ЧБ

\begin{tabular}{|c|c|c|c|c|c|}
\hline \multirow{3}{*}{$\begin{array}{c}\text { Комбінація } \\
\text { генотипів }\end{array}$} & \multicolumn{2}{|c|}{ Група } & \multirow{2}{*}{\multicolumn{3}{|c|}{$\begin{array}{c}\text { Результати статистичного } \\
\text { аналізу }\end{array}$}} \\
\hline & -ша & 2-га & & & \\
\hline & $\mathbf{n}$ & & ВШ & $95 \%$ ДI & $\mathbf{p}$ \\
\hline \multicolumn{6}{|c|}{ G80A/FGB C148T } \\
\hline $00 r$ & 14 & $8,7 \overline{6}$ & $4,54 \quad 2,65$ & 10 & 0,033 \\
\hline \multicolumn{6}{|c|}{ RFC1_G80A/ITGA2a_C807T } \\
\hline $80 \mathrm{AA} /$ & 8,7 & 10,73 & $6,61 \quad 12,9$ & $1,53-109,8$ & 0,010 \\
\hline \multicolumn{6}{|c|}{ RFC1_G80A/ITGB3b_T1565C } \\
\hline $80 \mathrm{AA} / 1$ & 4,3 & 0,00 & 6,05 & - & 0,014 \\
\hline \multicolumn{6}{|c|}{ RFC1_G80A/FSHr_Ala307Thr } \\
\hline GA & 8,7 & $28 \quad 20,44$ & $4,59 \quad 0,37$ & -0.94 & 0,033 \\
\hline \multicolumn{6}{|c|}{ FSHr Ala307Thr/FGB G-455A } \\
\hline 7Ala/Thr/- & 1014 & $8 \quad 5,84$ & $3,95 \quad 2,73$ & $1,04-6,78$ & 0,041 \\
\hline \multicolumn{6}{|c|}{ FSHr_Ala307Thr/MTRR_A66G } \\
\hline 77 & 13, & 4,38 & $\overline{5}, 10 \quad 3,28$ & $1,12-9,62$ & 0,024 \\
\hline \multicolumn{6}{|c|}{ FSHr_Ala307Thr/MTR1_A2756G } \\
\hline 307Ala/Ala/2756AA & 11 & 5,84 & $4,45 \quad 3,06$ & $1,17-8,00$ & 0,035 \\
\hline
\end{tabular}

Частота генотипів 307Ala/Ala та 680Ser/Ser за геном FSHr достовірно частіше переважала в 1-й групі $(26,09 \%)$ порівняно з 2-ю (14,60\%) ( $\chi^{2}=4,03, p=0,045 ;$ ВШ 2,06; 95\% ДІ 1,01-4,23), для варіантів гена $F S H r$ в українській популяції доведена асоціація зі ступенем фрагментації ДНК (>20\%) у сперматозоїдах у чоловіків віком $<35$ років, а також асоціація поліморфних генів фолатного обміну з рівнем анеуплоїдії сперми (Жилкова Е.С., 2017). У виконаному нами дослідженні наявність генотипу 80GA за геном RFC1 в поєднанні з генотипом 307Thr/Thr за геном FSHr знижувала ризик розвитку безпліддя (див. табл. 4). Останній був підвищеним за наявності комбінації генотипу 307Ala/Ala за геном FSHr з генотипами 66AG за геном MTRR та 2756AA - за геном MTR1.

Методом бінарної логістичної регресії отримано дві значущі прогностичні моделі, які ґрунтувалися на міжгенній та ген-факторній взаємодії генів фолатного обміну та гена FSHr (табл. 5).

Таблиця 5. Значущі прогностичні моделі міжгенної та ген-факторної взаємодії у розвитку безпліддя

\begin{tabular}{|c|c|c|c|c|c|}
\hline Показник & $\begin{array}{c}\text { Коефіці- } \\
\text { єнт } \\
\text { регресії }\end{array}$ & $\begin{array}{c}\text { Стан- } \\
\text { дартна } \\
\text { помилка }\end{array}$ & $\begin{array}{l}\text { Значу- } \\
\text { щість } \\
\text { відмін- } \\
\text { ностей }\end{array}$ & ВШ & 95\% ДI \\
\hline $\begin{array}{l}1298 \mathrm{AC} / 677 \mathrm{CT} / \\
2756 \mathrm{AG} / 80 \mathrm{AA}\end{array}$ & 1,744 & 0,845 & 0,039 & 5,719 & $1,091-29,972$ \\
\hline $\begin{array}{l}\text { Константа } \\
\text { 1298АC/677СТ/2756AG/ } \\
\text { 80АА/тютюнопаління }\end{array}$ & $\begin{array}{c}-0,645 \\
1,803\end{array}$ & $\begin{array}{l}0,218 \\
0,837\end{array}$ & $\begin{array}{l}0,003 \\
0,031\end{array}$ & $\begin{array}{l}0,525 \\
6,089\end{array}$ & $\stackrel{-}{-}$ \\
\hline $\begin{array}{l}\text { Константа } \\
\text { 307Ala/Thr/66GG/ } \\
\text { обтяжена спадковість }\end{array}$ & $\begin{array}{c}-0,704 \\
1,292\end{array}$ & $\begin{array}{l}0,184 \\
0,650\end{array}$ & $\begin{array}{l}0,000 \\
0,047\end{array}$ & $\begin{array}{l}0,494 \\
3,640\end{array}$ & $\frac{-}{1,018-13,013}$ \\
\hline Константа & $-0,732$ & 0,172 & 0,000 & 0,481 & - \\
\hline
\end{tabular}

Комбінація гетерозиготного варіанта гена $F S H r$ з мутантним генотипом MTR1 та обтяженою спадковістю була серед достовірних прогностичних моделей ризику безпліддя. У пацієнтів із гетерозиготними варіантами спадковість була обтяжена серцевосудинними та онкологічними захворюваннями, тромботичними станами і репродуктивними розладами у родичів 1-го та 2-го ступеня спорідненості. Більшу прогностичну цінність мали моделі, побудовані на аналізі взаємодій генів фолатного обміну. Наявність у пацієнтів комбінацій гетерозиготних варіантів за генами MTHFR, MTR1 та генотипу 80AA за геном RFC1 підвищувала ризик безпліддя у 5,7 раза, а за наявності тютюнопаління цей ризик зростав у $>6$ разів. Отже, тютюнопаління призводило до підвищення ризику безпліддя у пацієнтів із варіантами генів фолатного обміну, за яких знижена функціональна активність ензимів, а у разі MTR1, навпаки, - підвищена. Виявлення серед чоловіків репродуктивного віку - курців поліморфних варіантів генів фолатного обміну вкрай необхідне для персоналізованого призначення вітамінно-нутрієнтних препаратів. Для цих чоловіків без персоналізованого підходу у призначенні вітамінів групи В та фолієвої кислоти суттєво підвищується ризик не лише зниження репродуктивної функції, а й розвитку фатальних серцево-судинних подій. Опосередкована ознака цього ризику - висока частота виявлення серед пацієнтів обох груп ГГЦ, зумовленої мутаціями у генах фолатного обміну (аутосомно-рецесивного спадкового метаболічного захворювання, за останньою редакцією Міжнародної класифікації хвороб 10-го перегляду) 
У пацієнтів обох груп були підвищеними показники середнього рівня гомоцистеїну $(12,01 \pm 0,92$ та $18,16 \pm 1,80)$, які, окрім цього, значуще розрізнялися між собою. Виявлена ГГЦ, спричинена поліморфізмом генів фолатного обміну, у більше ніж $1 / 3$ чоловіків обох груп є важливим патогенетичним чинником у розвитку безпліддя невстановленого генезу та ранніх репродуктивних втрат у подружніх парах. Пацієнти з ГГЦ, спадковим метаболічним захворюванням, потребують медичних втручань, а саме персоналізованого призначення вітамінно-нутрієнтних препаратів для запобігання безпліддю та раннім репродуктивним втратам і серцевосудинним захворюванням.

\section{Висновки}

1. Виявлено асоціацію генів ITGB3b, ITGA2а та їх комбінацій зі зростанням ризику безпліддя. Значущими у розвитку ЧБ були 3-локусна прогностична модель міжгенної взаємодії (PAl-1 + ITG3b + ITGA2a) та 2-локусна прогностична модель ген-факторної взаємодії (ITGB3b + показник протромбінового часу).

2. Встановлено асоціації генотипу 80AA за геном RFC1 у поєднанні з генами фолатного обміну та гемостазу зі зростанням ризику безпліддя. Значущими були 4-локусна модель міжгенної взаємодії та модель ген-факторних взаємодій, побудована на варіантах гена MTHFR, MTR1, RFC1 і тютюнопаління.

3. Встановлено асоціацію алельних варіантів 307Ala/Ala і 680Ser/Ser гена FSHr та їх комбінацій із варіантами генів фолатного обміну з розвитком безпліддя, а значуще прогностичною була модель ген-факторних взаємодій, яка включала варіанти генів FSHr, MTRR та обтяжену спадковість.

4. Аналіз асоціації саме певних поліморфних варіантів генів різних метаболічних ланок між собою та у поєднанні з негенетичними факторами дозволяє говорити про значну гетерогенність ЧБ і необхідність формування персоніфікованого підходу в лікуванні.

\section{Список використаної літератури}

Горовенко Н.Г., Кирьяченко С.П., Россоха З.И. (2011) Изучение ассоциации полиморфных вариантов генов $A C E(I / D), A T 2 R 1$ (A1166C), TNF-a (G308A), MTHFR (C677T) и их комбинаций с риском развития перинатальной патологии и сокращением сроков гестации. Biopolym. Cell, 27(3): 206-213.

Жилкова Е.С. (2017) Генетичні аспекти репродуктивної функції у чоловіків у східній Україні. автореф. ... канд. біол. наук. Київ, 25 с.

Зотова Т.Ю., Мяндина Г.И. (2013) Влияние полиморфизма гена ITGB3 на частоту развития артериальной гипертензии у больных с острым коронарным синдромом. Клин. мед., 8: 22-27.

Abarikwu S.0. (2013) Causes and risk factors for male-factor infertility in Nigeria: a review. Afr. J. Reprod. Health, 17(4): 150-166.

Agarwal A., Mulgund A., Hamada A., Chyatte M.R. (2015) A unique view on male infertility around the globe. Reprod. Biol. Endocrinol., 13: 37.

Bueno O., Molloy A.M., Fernandez-Ballart J.D. et al. (2016) Common Polymorphisms That Affect Folate Transport or Metabolism Modify the Effect of the MTHFR 677 C $>$ T Polymorphism on Folate Status. J. Nutr., 146(1): 1-8.

Devalia V., Hamilton M.S., Molloy A.M.; British Committee for Standards in Haematology (2014) Guidelines for the diagnosis and treatment of cobalamin and folate disorders. Br. J. Haematol., 166(4): 496-513.

Gelineau-van Waes J., Maddox J.R., Smith L.M. et al. (2008) Microarray analysis of E9.5 reduced folate carrier (RFC1; SIc19a1) knockout embryos reveals altered expression of genes in the cubilin-megalin multiligand endocytic receptor complex. BMC Genomics, 9: 156.

Hong H.H., Hu Y., Yu X.Q. et al. (2017) Associations of C677T polymorphism in methylenetetrahydrofolate reductase (MTHFR) gene with male infertility risk: A meta-analysis. Eur. J. Obstet. Gynecol. Reprod. Biol., 212: 101-109.

Jungwirth A., Diemer T., Dohle G.R. et al. (2015) Guidelines on Male Infertility (https://uroweb.org/wp-content/uploads/17-Male-Infertility_LR1.pdf).

Kliesch S. (2014) Diagnosis of Male Infertility: Diagnostic Work-up of the Infertile Man. Eur. Urol., 13: 73-82.

Kucharska-Newton A.M., Monda K.L., Campbell S. et al. (2011) Association of the platelet GPIIb/Illa polymorphism with atherosclerotic plaque morphology: the Atherosclerosis Risk in Communities (ARIC) Study. Atherosclerosis, 216(1): 151-156

Massart A. , Lissens W., Tournaye H., Stouffs K. (2012) Genetic causes of spermatogenic failure. Asian J. Androl., 14(1): 40-48.

Pietrzik K., Bailey L., Shane B. (2010) Folic acid and L-5-methyltetrahydrofolate: comparison of clinical pharmacokinetics and pharmacodynamics. Clin. Pharmacokinet., 49(8): 535-548.

Rossokha Z., Gorovenko N. (2017) Assessment of the individual folic acid doses requirement for patient with reproductive disorders. J. Perinat. Med., 45(2): 349.
Stanger O., Herrmann W., Pietrzik K. et al. (2003) DACH-LIGA homocystein (german, austrian and swiss homocysteine society): consensus paper on the rational clinical use of homocysteine, folic acid and B-vitamins in cardiovascular and thrombotic diseases: guidelines and recommendations. Clin. Chem. Lab. Med., 41(11): 1392-1403.

Taneja S.S. (2014) Current management of male infertility. Urol. Clin. North Am., 41(1): xv.

Visentin M., Diop-Bove N., Zhao R., Goldman I.D. (2014) The intestinal absorption of folates. Ann. Rev. Physiol., 76: 251-274.

Wilcken B. (2017) Therapeutic targets in homocystinuria due to cystathionine $\beta$-synthase deficiency: new European guidelines. Exp. Opin. Orph. Drugs, 5: 1-3.

Wosnitzer M.S. (2014) Genetic evaluation of male infertility. Transl. Androl. Urol., 3(1): 17-26.

Zorrilla M., Yatsenko A.N. (2013) The Genetics of Infertility: Current Status of the Field. Curr. Genet. Med. Rep., 1(4) (https://www.ncbi.nlm.nih.gov/pmc/articles/PMC3885174/).

\section{Особенности межгенного и ген-факторного взаимодействия \\ у мужчин из супружеских пар с бесплодием и репродуктивными потерями}

\section{Н.Г. Горовенко, З.И. Россоха, С.П. Кирьяченко, Л.П. Шейко, Л.И. Бришевац}

Резюме. Проанализировано межгенное иген-факторное взаимодействие полиморфных вариантов генов гемостаза: ITGA2a (C807T), ITGB3b (T1565C), FGB (C148T, G-455A), PAI-1 (-675 5G/4G), FII (G20210A), FV(G1691A), фолатного обмена: MTHFR(C677T, A1298C), MTRR(A66G), MTR1 (A2756G), RFC1 (G80A) и гена рецептора фолликулостимулирующего гормона FSHr (Ala307Thr, Ser680Asn) у 206 мужчин из супружеских пар с бесплодием неустановленного генеза и ранними репродуктивными потерями. Проведено сравнение полученныхрезультатов с применением методов одно- имногофакторного анализа. Доказано наличие ассоциации генов ITGB3b, ITGA2a, RFC1, FSHr и их комбинаций с риском развития бесплодия умужчин. Значимыми были пять прогностических моделей риска: межгенного взаимодействия (PAI-1 + ITGB3b + ITGA2a, MTHFR + MTR1 + RFC1) и генфакторного взаимодействия (ITGB3b + протромбиновое время, MTHFR + MTR1 + RFC1 + курение, FSHr + MTRR + отягощенная наследственность). Выявленные зависимости указывают на разнообразие индивидуальных патогенетических механизмов развития бесплодия у мужчин, что требует применения персонализированного лечения.

Ключевые слова: генетический полиморфизм, репродуктивные расстройства, мужчины.

\section{Features of gene-gene and gene-factor interactions in men from couples with infertility and reproductive losses}

\section{N.G. Gorovenko, Z.I. Rossokha, S.P. Kiryachenko, L.P. Sheiko, L.I. Brisevac}

Summary. Gene-gene and gene-factor interactions of genes polymorphic variants of hemostasis: ITGA2a (C807T), ITGB3b(T1565C), FGB (C148T, G-455A), PAl-1 (-675 5G/4G), FII (G20210A), FV (G1691A), of folate metabolism: MTHFR (C677T, A1298C), MTRR(A66G), MTR1 (A2756G), RFC1 (G80A) and follicle-stimulating hormone receptor gene $\mathrm{FSHr}$ (Ala307Thr, Ser680Asn) has been analyzed in 206 men from couples with unexplained infertility and early reproductive losses. A comparison of obtained results conducted using the methods of single - and multivariate statistical analysis. The association of ITGB3b, ITGA2a, RFC1, FSHr genes and their combinations with the risk of infertility in men has been proven. Five prognostic risk models were significant: gene-gene interaction (PAI-1 + ITGB3b + ITGA2a, MTHFR + MTR1 + RFC1) and gene-factor interaction (ITGB3b + prothrombin time, MTHFR + MTR1 + RFC1 + smoking, FSHr + MTRR + hereditary burden). The founded dependencies indicated a variety of individual pathogenetic mechanisms in development of men infertility that requires the use of personalized treatment.

Key words: genetic polymorphism, reproductive disorders, men.

\section{Адреса для листування:}

Россоха Зоя Іванівна

04112, Київ, вул. Дорогожицька, 9

Д3 «Референс-центр з молекулярної діагностики М03 України»

E-mail: zoiroh071@gmail.com 